\title{
Digital Transformation of English Language Teaching (ELT) at a Technical University: BMSTU Case Study
}

\author{
Tatiana D. Margaryan ${ }^{1 *}$ and Liliya V. Kalugina ${ }^{1}$ \\ ${ }^{1}$ Bauman Moscow State Technical University, 2nd Baumanskaya str., 5/1, 105005, Moscow, Russia
}

\begin{abstract}
In order to survive and evolve the humanity needs changes and transformation. Changes in education are of particular importance because education plays a crucial role in creating a sustainable future. Today, we are undergoing digital transformation in all areas of our life, but educational institutions are only taking the first steps to become digital. Digital transformation of education should involve not only using computers at classes but designing new methods of teaching and learning as well. Technologies should benefit education. The purpose of this work is to share the successful experience of educators of the English for engineering technologies department at Bauman University in designing a new multimedia two-year English course for undergraduates at technical universities. The course "English in the Digital Age" includes a Student's Book in the digital format with integrated audio and video authentic materials, a Workbook with the key and mock tests, a Teacher's Resource Book with detailed teaching notes and an online course for English grammar drilling with an answer reveal function and personalized testing with automatic assessment. The course essential feature is that an online self-study grammar course and face-to-face learning process are successfully combined and personalized. The benefit of the work is the best practice in creating a basis for digital transformation of learning and teaching English at a technical university.
\end{abstract}

\section{Introduction}

Today, higher education in Russia is challenged with needs for digital transformation. Many researchers believe that the social and economic health of countries will even more depend on the quality of education of their citizens. The advent of a so-called "knowledge society", the transformation of information and media require a high level of qualification

\footnotetext{
* Corresponding author: t.margaryan@bmstu.ru
} 
and knowledge. That is why modern education systems must be effective and efficient in order to achieve their goals.

The system of higher professional education in Russia is going through a difficult period of reforms. This process affected not only the structure, but also the content of the educational process in higher education. The requirements for the professional competencies of graduates including English proficiency have increased. At the same time the number of academic hours for in-class learning remains the same or even reduced. Teachers of English faced a problem: how to solve this contradiction? The Federal State Educational Standard (FSES) defines students' workload as a combination of their class work and individual independent work. This means that the student's individual work must be carefully planned, effectively organized and systematically checked [1]. Therefore, educators of English for engineering department of Bauman University came up with an idea to design a new English course applying digital technologies and a blended learning technique. Transformation of education technologies should give a way to new forms of individual, pair and group work, without which it is impossible to form social and communicative skills of professionals.

The purpose of this paper is to share the best practice of BMSTU English teachers (L-3 department) in creating a new two-year multimedia English course for future engineers "English in the Digital Age", including a Student's book with integrated authentic audio and video materials, a Workbook which contains a variety of practice exercises that review grammar and language areas presented in the Student's book with the key and mock tests $[2,3]$, teaching notes and an online course for English grammar drilling with an answer reveal function and personalized testing with automatic assessment. (Fig.1). Online testing allows our students to try a mock test before a real one thus making the process less stressful. We are able to personalize learning more now than ever.
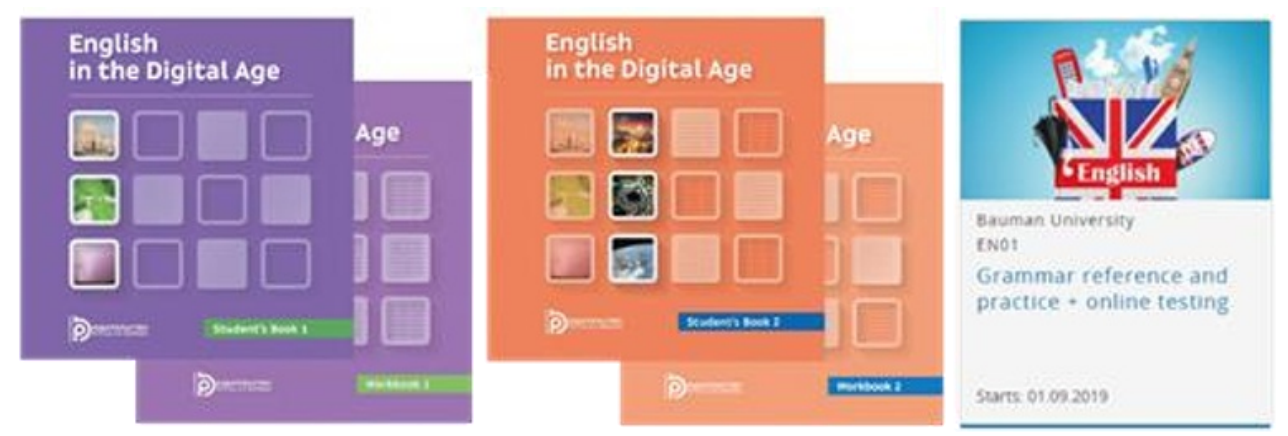

Fig. 1. A new English course: "English in the Digital Age

\section{Innovative teaching techniques}

Through the digital transformation and the rise of educational technology, teachers have begun making drastic changes to their instruction, assessments at a much faster rate than expected. New teaching approaches and education innovations have recently appeared. One of the most beneficial is blended learning. This innovative technique was driving while designing the multimedia course since blended learning gives more responsibility to students, as it involves less direct instruction from the teacher and more discovery-based methods of learning. Blended learning is an example of how students can control certain elements of their learning by making decisions about things like where and at what pace they move through material [4]. Another innovative technique is adaptive learning [5]. It is similar to blended in that it, too, allows students to make decisions about things like the 
timeframe and path of their learning. Adaptive learning technology collects information about student behavior as they're answering questions, and then subsequently uses that information to provide instant feedback in order to adjust the learning experience accordingly.

The use of innovative teaching methods should be an essential skill for English teachers in tertiary/vocational education. The term innovation (English innovation from Latin innovatio), which is translated from English as something new, innovative [6], was introduced into the scientific literature by the economist and sociologist Joseph Schumpeter, who considered the innovation as a source of development [7]. Pedagogical innovation, in contrast to pedagogy, is a relatively young branch of science but recently it has attracted genuine interest from an increasing number of teachers and educators [8-20]. They made a significant contribution to the study and development of educational innovative methods.

A. V. Khutorskoy studied the issue of innovative methods development and their implementation in the learning process and offered the following definition of the pedagogical innovation: "A pedagogical innovation refers to the doctrine of creating pedagogical innovations, their evaluation and development by the pedagogical community, their use and application in practice" [21]. Researchers Brewer and Tierney [22] believe that an innovation can be the result of inspiration, continuous creative and mental activity of a teacher or it can be "pushed" by new available technologies. Any innovation includes three main stages: the birth of an idea, its implementation and the result that is the result of the idea which leads to a change. In education, innovations can manifest themselves in the form of a new pedagogical theory, methodological approach, teaching technique, educational tool, educational process or institutional structures, which, when implemented, produce significant changes in teaching and learning that results in better student learning. Thus, innovations in education are designed to increase the productivity and effectiveness of training and / or improve the quality of training [23]. But it should be noted that the efficiency of teaching depends not only on innovative technologies or training, but on students' potential learning, intellectual, emotional and psychological abilities. All innovations are ultimately aimed at changing qualitative and / or quantitative indicators of learning outcomes:

- qualitative: better knowledge, more effective skills, important competencies, personal and professional development, advantageous employment and high working efficiency;

- quantitative: improved training parameters, such as test results, the amount of gained information, the number of acquired skills or competencies [24].

There is another way to evaluate innovation: it can be assessed by novelty, originality and a potential effect.

If we analyze the current innovations in education, we can see that the vast majority of them are associated either with technological electronic devices (laptops, tablets, and smartphones) or with technological training systems and materials, e.g. the Learning Management System (LMS), educational software and web resources. A technology has always served as both a driving force and an instrument of innovation in any area of human activity. Information and communications technologies (ICT) have firmly established itself in our educational system. The role of ICT in learning English has changed over time, especially in recent years since not only the opinion on teaching English has changed from behaviorist to communicative and integrative, but technologies have become more common in everyday life, especially in the professional world. This all impacted the way the ICT is used in English classes today. Here are the main benefits of using the ICT in English classes [25]:

1. It provides communication and students interaction.

2. It promotes understanding the cross - cultural issues in various fields and professions. 
3. It provides profession insight and enhances student learning productivity.

4. It utilizes authentic materials in specific disciplines and professions.

5. It creates an authentic audience including external experts in specific areas.

6. It develops students' cognitive abilities and critical thinking skills.

7. It provides collaborative learning.

8. It focuses on learners and considers their specific needs.

9. It meets the emotional needs of students and increases their motivation to learn a foreign language.

10. It promotes students autonomy and individualization of learning.

An important distinguishing feature of innovative technologies is their interactivity, the involvement of students in the learning process, the transition from informative forms of learning to active ones when learning becomes not the translation of knowledge but the active production of independent ideas and students' collaboration. Therefore, blended learning is gaining more and more popularity. For traditional universities a blended learning environment is natural, as it offers a bridge between traditional practice and online education [26]. Teaching and training in blended forms provides a learning environment that improves real - time interaction with teaching materials, discussions with teachers and classmates, as well as the opportunity to provide effective feedback without having to wait until the "next meeting in class" as it often happens in traditional teaching environment. The driving factor for increasing use of blended learning is that present-day students are the generation used to get immediate results by interacting with technological devices. Thus, such students expect a similar experience of "convenience and flexibility" from their educational process.

When we discuss innovative educational technologies, we cannot but consider the opportunities of multimedia tools that can be used in teaching English. Multimedia is an interdisciplinary technology that uses the multisensory nature of people, since we usually use several senses - sense of sight and hearing to communicate with each other. Among the advantages of multimedia educational tools is that it enables to present various aspects of the English language with the help of video, audio, animation, etc. and therefore, new ideas become more clear. Moreover, multimedia makes students more involved in the classroom activities and assists them in learning new information in a foreign language.

In order to prepare comprehensive and effective multimedia, it is important to know the basic principles of using multimedia [27]:

1) a complementary principle: to ensure a better memorizing and understanding the subject, various aspects of one issue should be presented in different media formats in an additional order;

2) relevance to the topic: the components of multimedia presented in various media (video, pictures, graphics and diagrams) should match and create an unified whole;

3) compatibility of a new material with the knowledge obtained by students previously: images, diagrams, signs, symbols or other multimedia information should be clear to students who are to comprehend the received information;

4) possibility to download provided information: preparing multimedia tools for an English class, especially audio and video recordings, a teacher must make sure that authentic teaching tools are presented at a controlled speed and there will be no overload of students' ability to process the information.

Multimedia tools help create a creative environment in a classroom and increase students' motivation. We considered all the advantages of the above mentioned innovative educational technologies while designing a new course in English for engineering students. 


\section{Materials and Methods}

When designing teaching materials, it is important to arrange and structure them properly [28]. Considering the requirements of the Federal State Educational Standard to a foreign language competence of engineering students, we have developed materials for a new course in English on a module basis. We have designed a range of tasks for each module taking into account the specific features of cultural, scientific, professional competences of future graduates since modules can vary not only in content, but also in terms of language complexity but keeping a single topic for the module. Modules are easy to combine. The modular course is more mobile and flexible, while the diversification of the content is easily maintained.

The target audience of the course is undergraduates - students of the 1 st and 2 nd years of study. A multimedia course book and online course are designed for 136 in-class hours (4 terms, 17 academic weeks per term, 2 academic hours per week) and consists of four parts, each of which includes 3 modules. Modules cover various areas of communication: socio-cultural, educational, cognitive and professional. The authors used competency-based and professionally-oriented approaches.

The course book is well structured. Each module consists of four lessons, each of which contains a variety of lexical and grammar exercises, there are assignments for listening and for stimulating spontaneous statements on the topic that facilitate speaking and listening skills. At the end of each module there is a brief topical vocabulary that students can use in classes or when they work independently at home. The main vocabulary to be mastered is presented at the beginning of each module. The material of each module includes topical issues for discussions, short texts related to the subject of the discussion, several video or audio files to foster listening skills and exercises to develop students' speaking skills.

Before designing a new course, teachers of the department were invited to take part in a survey developed by our colleagues. The questionnaire included a number of questions, ranging from the teachers' age and proficiency level to the various teaching methods and techniques used in the class, for example:

\section{My students do the following activities in class:}

Reading activities:

- Reading aloud: often $65 \%$; sometimes 30\%; seldom 5\%; never $0 \%$

- Silent reading (for general/specific information): often $35 \%$; sometimes $60 \%$; seldom $5 \%$; never $0 \%$

- Text comprehension exercises, e. g. true/false statements, key questions, putting items in the right order:

often $60 \%$; sometimes $40 \%$; seldom $0 \%$; never $0 \%$

- Predicting before reading/listening: often $17.6 \%$; sometimes $52.9 \%$; seldom $23.5 \%$; never $5.9 \%$

- Guessing the meaning of words from context: often $52.9 \%$; sometimes $35.3 \%$; seldom $11.8 \%$; never $0 \%$

- Translating terminology: often $70.6 \%$; sometimes $23.5 \%$; seldom $5.9 \%$; never $0 \%$

Writing activities:

- Doing writing tasks (e. g. drafting, editing, and revising the text): 
often $35 \%$; sometimes $17.6 \%$; seldom $41.2 \%$; never $5.9 \%$

- Writing abstracts:

often 11.8\%; sometimes $47.1 \%$; seldom $29.4 \%$; never $11.8 \%$

Speaking activities:

- Brainstorming: often 25\%; sometimes $50 \%$; seldom 25\%; never $0 \%$

- Oral summarizing: often $47.1 \%$; sometimes $52.9 \%$; seldom $0 \%$; never $0 \%$

- Discussion-debate:

often $41.2 \%$; sometimes $47.1 \%$; seldom $11.8 \%$; never $0 \%$

- Making presentations:

often 52.9\%; sometimes $41.2 \%$; seldom $5.9 \%$; never $0 \%$

- Simulation of a professional activity/ a role play: often $25 \%$; sometimes $31.3 \%$; seldom $31.3 \%$; never $12.5 \%$

Listening activities:

- Listening for general/specific information: often $847.1 \%$; sometimes $47.1 \%$; seldom $5.9 \%$; never $0 \%$

- Pronunciation work: often $17.6 \%$; sometimes $47.1 \%$; seldom $35.3 \%$; never $0 \%$;

In class I try to teach my students to:

- Listen to lectures and take notes: always $11.8 \%$; often $17.6 \%$; seldom $52.9 \%$; never $17.6 \%$

- Read and understand specialist / vocationally-orientated literature always $47.1 \%$; often $52.9 \%$; seldom $0 \%$; never $0 \%$

- Speak on everyday topics: always $17,3 \%$; often $47.1 \%$; seldom $35.3 \%$; never $0 \%$

- Speak on professional topics: always $17.6 \%$; often $70.6 \%$; seldom $11.8 \%$; never $0 \%$

How much use do you make of:

Course books published abroad

Course books published in Russia

Home-made materials/booklets

Personal set of photocopied materials

I have ready access to the following:

$\begin{array}{ll}\text { Computer } & 85 \% \\ \text { E-mail } & 70 \% \\ \text { Internet } & 65 \% \\ \text { Video } & 60 \% \\ \text { Tape-recorder /player } & 60 \% \\ \text { Photocopier } & 55 \%\end{array}$

$$
\begin{aligned}
& 63.2 \% \\
& 63.2 \% \\
& 84.2 \% \\
& 63.2 \%
\end{aligned}
$$

$85 \%$

$70 \%$

$60 \%$

$60 \%$

$55 \%$

Analysis of the questionnaire results helped in the material selection and the development of tasks. To make the course efficient and beneficial for our students we asked them about the most difficult activities in learning English and what could facilitate their EL learning. The results are presented on the charts (fig. 2, fig. 3). We used that information to provide instant feedback in order to adjust their learning experience 
accordingly. They helped us to distribute and focus teaching materials in modules and online course.

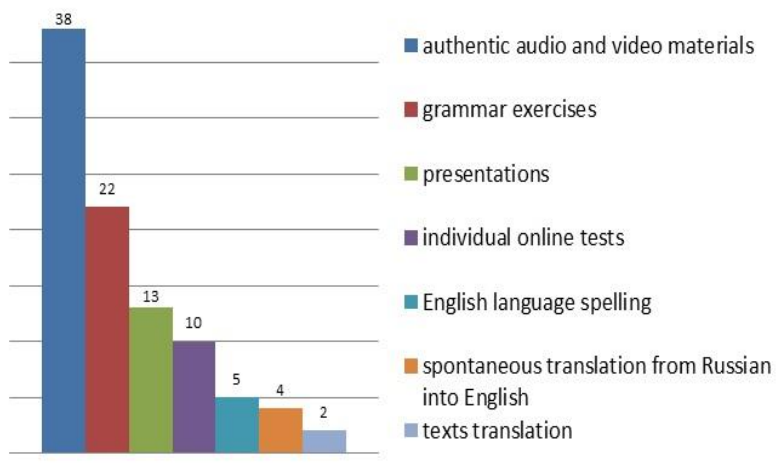

Fig. 2. The most difficult activities for students

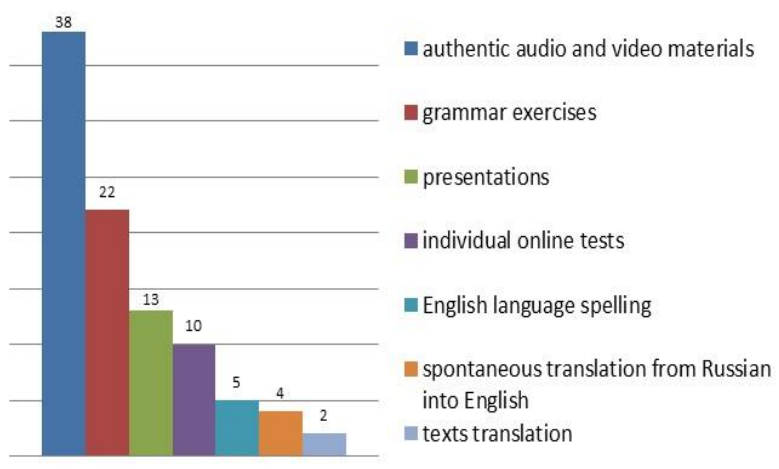

Fig. 3. Students suggestions on EL learning

\section{Results}

To drive innovation, an adequate level of knowledge and skills are essential. One of the conditions to create an effective English course is the integration of modern innovative teaching techniques and digital technologies, as well as creation of an effective system of multi-level language proficiency evaluation, which will help maintain continuity at all stages of training and provide the necessary level of integration. We decided to develop a course which students could benefit for developing their speaking skills. So, all classroom activities are designed so that students are able to use every minute for their speaking skills development. Designing a new course book, we considered not only the amount of knowledge that our students should possess or their shaped skills, but also their cognitive abilities and socio-cultural experience. It is well known that students easily master a foreign language when the material is interesting and its complexity corresponds to the level of students' language proficiency. Therefore, topics for discussion were carefully selected. Engineering students are primarily passionate about the study of engineering subjects [29]. In this regard, the topics of the modules were selected so that they were interesting and familiar to students, for example: "Renewable energy sources", "Communication technologies", "Robotics and artificial intelligence", "Innovative technologies", "Spaceenabled materials", etc. 
To create a communicative environment, the choice of material and the selected vocabulary are not enough, but certain teaching techniques and tasks are required. The developed modules include many tasks for team-work, work in pairs, in small groups, when students discuss the watched video or read text (interactive approach). To inspire real-life situations, role-plays (interviews with famous scientists, preparation for the expedition to Mars, etc.), round table discussions and mini-conferences are offered. A number of web quests, presentations, debates, and project assignments, which are successfully used for speaking skills evaluation, were developed and integrated into the course. Learning activities in face-to-face learning highly appreciated by students are presented on the chart (fig.4). Completing the assignments students not only learn new vocabulary, gain additional knowledge on a specific topic, but also learn to analyze information, draw independent conclusions, work in a team, and advocate their point of view.

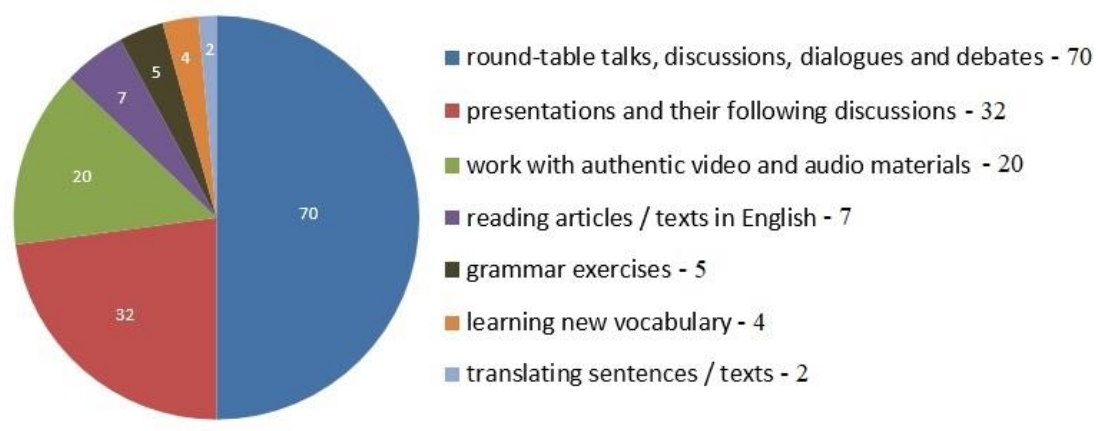

Fig. 4. Face-to-face learning activities highly appreciated by students

Due to the digital technologies students can study independently. The course book is published in two formats: hard and soft. The digitized version is easily downloaded to students' smartphones and tablets. It makes the multimedia tool available and attractive. Students don't need special equipment (computer, speakers, projector, and screen) to listen to dialogues or watch the training video. Thus, this approach allows us to individualize the learning process. Now the student can independently listen to or watch the video, pausing or repeating the passage again. This is a good motivation for the development of listening skills, which for many years was considered one of the most difficult in mastering English language.

The developed online grammar course enables students to drill grammar structures and do exercises with the individual pace as well. The course consists of English grammar theory (presented in a native language), grammar exercises for drilling, and a variety of tests. A test is formed automatically at the moment when a student starts doing it. It ensures an absolutely individual set of assignments. What is more essential for students is that they can make their own decisions what and when to train. Many of them don't need much grammar drilling and they can use their time for other activities. But those who need grammar drilling have unlimited opportunities to improve their grammar knowledge and skills. It leads to better test results (fig. 5). 


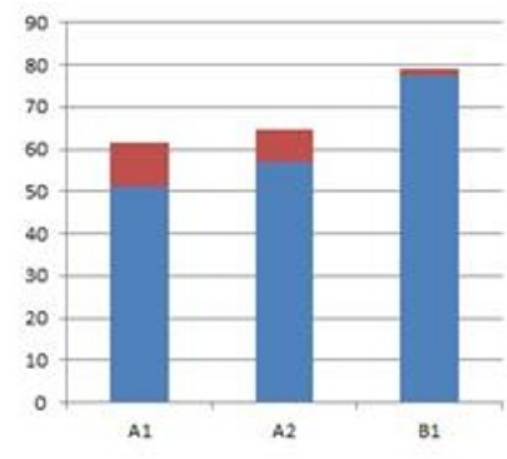

an students' tests results

with a high level of

grammar practice

= students' tests results

with a low level of

grammar practice

Fig. 5. Individual online grammar practice impact on students' tests results

Students' self-checking is another important issue that we managed to solve. A workbook was developed to consolidate the skills acquired at the classroom, and to develop the skills of independent work with information from the English-language information and educational resources. All the tasks presented in the workbook are coherent with the tasks for the classroom work and are similar to test tasks carried out at the end of each module. In addition to the workbook, students can check their knowledge and skills in the online course.

To evaluate the efficiency of the developed course, our colleagues were offered a questionnaire about the priority learning activities, the time allotted for each of them in a class, types and results of students' knowledge and skills assessment. The survey results are shown in Table 1 and Table 2 [30].

Table 1 Priority teaching and learning activities

\begin{tabular}{|c|c|c|c|}
\hline $\begin{array}{c}\text { Teaching and } \\
\text { Learning Activities }\end{array}$ & $\begin{array}{c}\text { Completed } \\
\text { (yes/no) }\end{array}$ & $\begin{array}{c}\text { Time Consumption } \\
\text { (min.) }\end{array}$ & $\begin{array}{c}\text { Time Distribution in } \\
\text { Class } \\
\text { Min. - Max. (\%) }\end{array}$ \\
\hline speaking & yes & $30-45$ & $30-50$ \\
\hline $\begin{array}{c}\text { lexical/grammar } \\
\text { exercises }\end{array}$ & yes & $15-20$ & $20-25$ \\
\hline listening & yes & 15 & $5-10$ \\
\hline reading & yes & $12-13$ & $10-15$ \\
\hline translation & yes & $8-10$ & $5-10$ \\
\hline writing & yes & $5-10$ & $5-10$ \\
\hline
\end{tabular}


Table 2 Students' English language proficiency evaluation

\begin{tabular}{|c|c|}
\hline Activity \& Assessment Types & $\begin{array}{c}\text { Results } \\
\text { \% }\end{array}$ \\
\hline Speaking: & 80 \\
Presentations & \\
Debates \\
Reports & \\
\hline Grammar /vocabulary: & 75 \\
\hline test & 95 \\
\hline Reading: & \\
T/F exercises & \\
Multiple choice & \\
Answers to questions & 75 \\
\hline Listening: & \\
T/F exercises & \\
Multiple choice & \\
Answers to questions & 78 \\
\hline Translation: & 60 \\
\hline Test & \\
\hline Writing: & \\
Letter (formal/informal) & \\
Paragraph & \\
Student's profile & \\
Form / application / invoice & \\
Short story & \\
Report & \\
Essay & \\
\hline
\end{tabular}

\section{Conclusion}

To create a solid digital transformation strategy, you must work collaboratively, identifying your core aims and goals, as well as the technologies, methodologies and innovations you will need to achieve them. A technology is considered innovative and effective when it reduces time and effort to accomplish the task, assists in obtaining more information and fosters the required competencies. In our case, this effect is obvious. The in-class learning activities have been redistributed from receptive types of learning activities to productive ones due to the designed course. The new digital technologies and innovative teaching techniques are exciting and offer previously unthinkable possibilities to students, but they require constant IT support. As educational institutions continue to jump on the bandwagon and adopt these digital transformation trends, we must consider the current paradigm for technology instruction and move toward a learner-based approach. As student expectations increase, our responsiveness to those needs must increase as well.

\section{References}

1. K.M. Inozemtseva, N.O. Troufanova, A.K. Krupchenko, Professional Development Model for ESP Teachers Working at Engineering Universities (in Russian), Vysshee obrazovaniie v Rossii = Higher Education in Russia, vol. 28, No. 1, pp. 147-158 (2019). DOI: https://doi.org/10.31992/0869-3617-2019-28-1-147-158. 
2. L.V. Kalugina, O.M Loseva, English in the Digital Age. Part 1, BMSTU, Moscow (2018). http://ebooks.bmstu.ru/catalog/108/book1885.html.

3. T. Borodina, L. Kalugina, T. Margaryan, English in the Digital Age. Part 2, BMSTU, Moscow (2018). http://ebooks.bmstu.ru/catalog/108/book1970.html.

4. N. Nurieva, T. Borisova, M. Kulikova, Application of Blended Learning in English Fiction Literature Course, ICDTE 2018 Proceedings of the 2nd International Conference on Digital Technology in Education. Bangkok, Thailand, pp. 23-28, ACM New York, NY, USA (2018). DOI: 10.1145/3284497.3284504.

5. G. Motteram, Innovations in learning technologies for English language teaching, London, UK: British Council, pp. 201 (2013).

6. Oxford Learner's

Dictionaries https://www.oxfordlearnersdictionaries.com/definition/english/innovation.

7. Y. Shumpeter, Capitalism, Socialism and Democracy. Economy (Russian translation), Moscow (1995).

8. S.D. Polyakov, Innovation studies: from an idea to practice (in Russian). Pedagogical search, Moscow (2007).

9. N.I. Sidnyaev, J.I. Butenko, V.V. Garazha, Mathematical apparatus for engineeringlinguistic models, AIP Conference Proceedings 2019, vol. 2195 (2019). https://doi.org/10.1063/1.5140133 doi: 10.1063/1.5140133.

10. I.V. Glasova, Application of innovative technologies as a tool to facilitate students' study at the university (in Russian). Dissertation for PhD in pedagogy. Moscow (2002)

11. M.A. Koroli, I.V. Sotnikova, Innovative teaching techniques in a technical university (in Russian), Concept Electronic Journal (2017). http://e-koncept.ru/2017/170037.htm.

12. G.J. Thomas, B. Munge, Innovative outdoor fieldwork pedagogies in the higher education sector: Optimising the use of technology, Journal of Outdoor and Environmental Education (2017). DOI: https://doi.org/10.1007/BF03400998.

13. A. Hargreaves, Teaching in the Knowledge Society: Education in the Age of Insecurity, Teachers College Press, New York (2003).

14. A. Hargreaves, D. Shirley, The Fourth Way: The Inspiring Future of Educational Change, Corwin, CA : Thousand Oaks ( 2009).

15. T. Heick, 12 Barriers to innovation in education, TeachThought (2016). https://www.teachthought.com/the-future-of-learning/12-barriers-innovationeducation/.

16. Y. Astatke et al., Improving and Expanding Engineering Education in the Middle East and Africa Using Mobile Learning Technology and Innovative Pedagogy, $\mathrm{M}$. Abdulwahed, M. Hasna, J. Froyd (eds) Advances in Engineering Education in the Middle East and North Africa. Springer, Cham. (2016). DOI: https://doi.org/10.1007/978-3-319-15323-0_10.

17. L. Jiang, Why education innovation is the most important thing you could pursue, Getting Smart, 920150. https://www.gettingsmart.com/2015/04/why-educationinnovation-is-the-most-important-thing-you-could-pursue.

18. L. Baer, J. McCormick, Building the capacity for change through innovation, A. Hoffman, S. Spangehl (eds), Innovation in Higher Education: Igniting the Spark for Success, American Council on Education, Lanham, MD: Rowman \& Litttlefield Publishers Inc, pp. 165-181. ( 2012). 
19. C.M. Christensen, H.J. Eyring, The Innovative University: Changing the DNA of Higher Education from the Inside Out, Tertiary Education and Management, Springer Netherlands (2012). DOI:. https://doi.org/10.1080/13583883.2011.646297.

20. A. Balla, A. Sarirete, Developing Educational Applications using Adaptive e-Learning Model, M. Iskander (eds), Innovative Techniques in Instruction Technology, Elearning, E-assessment, and Education, Springer, Dordrecht. (2008). DOI: https://doi.org/10.1007/978-1-4020-8739-4_3.

21. A. V. Khutorskiy, Pedagogical innovations as an educational driver (in Russian), 7th Russian National Conference on Innovations in Education. Eidos, Online journal (2005). http://eidos.ru/journal/2005/0910-19.htm.

22. D. Brewer, W. Tierney, Barriers to Innovation in the US Education, B. Wildavsky, A. Kelly, K. Carey (eds), Reinventing Higher Education: The Promise of Innovation, Cambridge, MA: Harvard Education Press, pp. 11-40 (2012).

23. F. Okpara, The value of creativity and innovation in entrepreneurship, Journal of Asia Entrepreneurship and Sustainability, vol. III, No. 2, pp. 2-14 (2007).

24. N.V. Komissarova, K. Gleason, P. G. Matukhin, Knowledge hub: spiral matrix thinking as a communication technology for individual and group learning in one drive and word online, Vestnik Rossiyskogo universiteta druzhby narodov = Bulletin of Russian University of Peoples Friendship, vol. 14., № 2. pp. 194-204. (2017).

25. I.I. Butenko, Ontology approach to normative profiles forming at critical software certification, AIP Conference Proceedings, vol. 2171. No. 1. AIP Publishing (2019). DOI: https://doi.org/10.1063/1.513323644.

26. I.I. Vasilieva, Blended learning ESP course: internet pedagogy, wiki-site \& design basing on the author's course (in Russian), Open and on-line education, № 3 (47), pp.67-72. (2012).

27. R. Parekh, Principles of Multimedia, 2nd ed. Tata McGraw H., Education Private Limited (2013).

28. G. Gurova, S.V. Reznik, I.R. Shafikova, New materials and developing English language competence in university students and teachers, Journal of Physics: Conference Series 2018, vol. 1134 , iss. 1 (2019). DOI: 10.1088/17426596/1134/1/012019.

29. I. Shafikova, G. Gurova, A. Novikov, Developing English language competence for specialists in rocket and space composite structures, MATEC Web of Conferences 2018, vol. 194 (2018). DOI: 10.1051/matecconf/201819401051.

30. T. Margaryan, N. Alyavdina, New Trends in Teaching English at a Russian Technical University, Handbook of Research on Engineering Education in a Global Context, pp. 274-284. Hershey, PA: IGI Global (2019). DOI: 10.4018/978-1-5225-3395-5.ch024. 